\title{
EFFECT OF SHIFRING TO DRIP IRRIGATION ON SOME PLUM CULTIVARS GROWN IN CLAY LOAMY SOIL
}

\author{
HUSSIEN, S.M. ${ }^{1}$, M. A. FATHI ${ }^{1}$ and T. A. EID ${ }^{2}$ \\ 1. Hort. Res. Inst., ARC, Giza \\ 2. Soils, Water and Enviro. Res. Inst., ARC, Giza
}

(Manuscript received 9 September 2012)

\begin{abstract}
This study was conducted on 23-years old plum trees (Golden Japanese, Dorado and Santa Rosa cultivars) budded on Mariana rootstock and planted at $5 \times 5 \mathrm{~m}$ apart on clay loamy soil under flood irrigation system (5180 and $5124 \mathrm{~m}^{3} /$ feddan/season) or drip irrigation system (2607.4 and $2553.6 \mathrm{~m}^{3} /$ fed./season) during 2010 and 2011 seasons, respectively.

Drip irrigation system supported an increase of vegetative growth parameters (shoot length, leaf area, leaf dry weight \%, number of leaves/shoot and foliation \%), fruit attributes (flowering $\%$, fruit set, number of fruits/tree and yield), fruit quality (weight, size, firmness, TSS and acidity), root length, root dry weight (roots $<2 \mathrm{~mm}$ and 2-6 mm) and water use efficiency $\left(1.94-2.5 \mathrm{~kg} / \mathrm{m}^{3}\right.$ fruits). While flood system increased leaf dry weight \%, root dry weight (roots $>6 \mathrm{~mm}$ ), as well as narrow and broad-leaf weeds spread. However some of these differences were not significant.

Golden Japanese plum cv. produced higher fruit set, yield, number of fruits/tree, as well as water use efficiency and less fruit juice acidity. While Santa Rose cv. resulted better foliation, fruit weight and size, as well as juice TSS and more suitable fruit firmness. Meanwhile larger leaves with much dry weight $\%$ and less fruit drop were proceeded from Dorado plum cv.

So we can recommend plum growers on clay loamy soil to converse flood irrigation system to drip system to save $50.1 \%$ of irrigation water with better growth, fruit yield, fruit quality, much water use efficiency and to reduce weed spreation.
\end{abstract}

\section{INTRODUCTION}

The plum (Prunus salicina) trees are related to the Japanese group and belongs to family Rosacease. The plum tree area in Egypt decreased from 8155 feddans (1993) to 2645 fed. in (2010) as a result of tree decline and unfruitfulness.

When all the controllable variables are optimized so as to avoid any occurrence of moisture stress during the growing season, many crops show a pronounced increase in yield. The desired effect can be produced by optimizing the quantity and increasing the frequency of irrigation, taking care to avoid wetting the soil excessively. This optimization is difficult to achieve by the traditional surface irrigation methods (flood system). The advantage of newer irrigation systems (drip system) has made it possible to establish and maintain soil moisture conditions at a 
more nearly optimal level. These new systems are capable of delivering water in controllable small quantities as after and as long as needed (Hillel, 1987).

The flood irrigation system is the main system used to irrigate plum orchards on clay loamy soil through El-Wady and Delta. Minimizing water use not only reduce production cost, especially where fertigation is a normal practices but also helps to meet the environmental regulation due to reduce the leaching of nutrients into ground water. On the other hand, maximizing the use of modern irrigation systems became essential to satisfy the increase of water demand (Brown, 1999) especially in arid and semiarid regions as Egypt where population is fast increasing.

Water requirements differ considerably with season, soil type and tree variety. When a tree suffers from lack of water, its yield decreases even though it may recover after irrigation. On the other hand, increasing the number of irrigation (or water quantity) may result in injuring the crop and the soil besides being a waste of water and labour. Fathi (1999) on pear and Fatma et al., (2009) on persimmon obtained better growth with $80 \%$ field capacity (F.C.). Also, Kandil and El-Feky (2006) showed that, water soil potential at 100-200 m bar (12.94 m³/tree/year) was the best rate for apricot trees. Water requirements values were estimated by Eid et al., (2002) in Delta from ET crop values by using irrigation efficiency of $60 \%$ for surface irrigation. Annual water requirements values for deciduous crops were estimated as $7420 \mathrm{~m}^{3} /$ fed./year for almond, apple, apricot, peach, pear, pecan and plum while were $5607 \mathrm{~m}^{3} /$ fed/year for fig and grape.

However, Levin et al., (1980) stated that, root distribution depended upon the volume of wetted soil which was related to soil hydraulic conductivity, rate and duration of water application. While discount of soil moisture resulted in reducing the size of the root zone subsequently the size of the root system and water consumption (Magriso, 1981). Layne-Rec et al., (1986) found that, location, number and roots diameter near the drip line were greatly affected by irrigation where total number and number of fine roots $(<2 \mathrm{~mm}$ ) were highest in non-irrigated plots while decreased with increasing irrigation. Furthermore, both fresh and dry weight of the root system increased progressively with increasing soil moisture from 40 to $80 \%$ F.C. on peach and Fathi (1999) on pear. On the other hand, Marler and Davies (1990) cleared that orange root dry weight was similar for high and moderate rates but was significantly reduced at low irrigation rate.

This study aims to identify the effects of transition from flood irrigation system to drip irrigation one as well as determines the most suitable irrigation scheduling for plum growth parameters, fruit attributes, fruit quality, root system growth, water use efficiency and weeds spread. 


\section{MATERIALS AND METHODS}

The present work was preformed at El-Kanater Hort. Res. Station for two seasons (2010 and 2011) in addition to prepared season through 2009 on 23-yearsold trees of three fruitful plum cultivars (Golden Japanese, Dorado and Santa Rosa). The selected trees were budded on Mariana rootstock and planted at $5 \times 5 \mathrm{~m}$ on clay loamy soil. The experimental soil was analyzed (Tables 1 and 2) according to Jackson (1958). The trees were subjected to standard fertilization, pruning and control programs recommended by the Ministry of Agriculture.

Applied water quantities were as fallows:

1- For drip irrigation system the rates 2607.4 and $2553.6 \mathrm{~m}^{3} /$ feddan/year (about 50 $\%$ of flood irrigation rates) as illustrated in Table (3). Two JR hoses with inter emitters at $50 \mathrm{~cm}$ apart were used for each trees row. Each emitter deliver $4 \mathrm{~L} / \mathrm{hr}$.

2- For flood irrigation system the rates 5180 and $5124 \mathrm{~m}^{3} /$ fed./year were applied for both seasons, practices for clay loamy soil (Eid et al., 2002).

Table 1. Water parameters and bulk density of soil.

\begin{tabular}{|c|c|c|c|c|c|c|c|}
\hline \multirow{2}{*}{$\begin{array}{l}\text { Depth } \\
\text { (cm.) }\end{array}$} & \multicolumn{2}{|c|}{$\begin{array}{l}\text { Field capacity } \\
\text { (FC) }\end{array}$} & \multicolumn{2}{|c|}{$\begin{array}{l}\text { Wilting point } \\
\text { (WP) }\end{array}$} & \multicolumn{2}{|c|}{$\begin{array}{c}\text { Available water } \\
\text { (AW) }\end{array}$} & \multirow{2}{*}{$\begin{array}{l}\text { Bulk density } \\
\text { (BD) } \mathrm{mg} / \mathrm{m}^{3}\end{array}$} \\
\hline & $\begin{array}{l}\% \text { by } \\
\text { weight }\end{array}$ & $\mathrm{mm}$ & $\begin{array}{l}\% \text { by } \\
\text { weight }\end{array}$ & $\mathrm{Mm}$ & $\begin{array}{l}\% \text { by } \\
\text { weight }\end{array}$ & $\mathrm{mm}$ & \\
\hline $0-30$ & 37.8 & 6.97 & 18.1 & 3.34 & 17.0 & 3.63 & 1.23 \\
\hline $30-60$ & 32.3 & 6.25 & 16.2 & 3.13 & 16.8 & 3.12 & 1.29 \\
\hline $60-90$ & 31.5 & 7.04 & 15.8 & 3.53 & 14.9 & 3.51 & 1.49 \\
\hline Total & & 20.26 & & 10.0 & & 10.26 & \\
\hline
\end{tabular}

F.C.: moisture at $33 \mathrm{Kpa}$ moisture tension.

WP: moisture at $1.5 \mathrm{Mpa}$ moisture tension.

$\mathrm{AW}=\mathrm{FC}-\mathrm{WP}$.

Table 2. Physical properties of the soil.

\begin{tabular}{|c|c|c|c|c|c|}
\hline $\begin{array}{c}\text { Particle size } \\
\text { distribution (\%) }\end{array}$ & Clay \% & Silt \% & $\begin{array}{c}\text { Fine sand } \\
\%\end{array}$ & $\begin{array}{c}\text { Coarse } \\
\text { sand (\%) }\end{array}$ & $\begin{array}{c}\text { Texture class } \\
(\%)\end{array}$ \\
\hline Value & 31.9 & 33.2 & 33.9 & 1.0 & Clay loam \\
\hline
\end{tabular}


Table 3. The quantity of irrigation water.

\begin{tabular}{|c|c|c|c|c|c|c|c|c|c|c|}
\hline \multirow{3}{*}{ Months } & \multicolumn{6}{|c|}{ Drip irrigation } & \multicolumn{4}{|c|}{ Flood irrigation } \\
\hline & \multicolumn{3}{|c|}{2010} & \multicolumn{3}{|c|}{2011} & \multicolumn{2}{|c|}{2010} & \multicolumn{2}{|c|}{2011} \\
\hline & $\mathrm{M}^{3} /$ tree & L/tree/day & $\mathrm{m}^{3} / \mathrm{fed}$ & $\mathrm{M}^{3} /$ tree & L/tree/day & $\mathrm{m}^{3} / \mathrm{fed}$ & $\mathrm{M}^{3} /$ tree & $\left(\mathrm{m}^{3} /\right.$ fed. $)$ & $\mathrm{M}^{3} /$ tree & ( $\mathrm{m}^{3} /$ fed. $)$ \\
\hline January & 0.16 & 5.16 & 26.88 & 0.15 & 4.84 & 25.20 & - & - & - & - \\
\hline February & 0.32 & 11.43 & 53.76 & 0.30 & 10.71 & 50.40 & 1.33 & 223 & 1.31 & 220 \\
\hline March & 1.26 & 40.65 & 211.68 & 1.20 & 38.71 & 201.60 & 2.04 & 342 & 1.99 & 335 \\
\hline April & 2.40 & 80.00 & 403.20 & 2.35 & 78.33 & 394.8 & 3.55 & 596 & 3.52 & 591 \\
\hline May & 2.72 & 87.74 & 457.00 & 2.70 & 87.10 & 453.6 & 4.42 & 743 & 4.27 & 717 \\
\hline June & 2.86 & 95.33 & 480.48 & 2.80 & 93.33 & 470.40 & 5.04 & 847 & 5.00 & 840 \\
\hline July & 2.40 & 77.42 & 403.20 & 2.36 & 76.13 & 396.48 & 4.73 & 796 & 4.70 & 790 \\
\hline August & 1.80 & 58.07 & 302.40 & 1.78 & 57.42 & 299.04 & 4.30 & 723 & 4.30 & 722 \\
\hline September & 0.71 & 23.67 & 119.28 & 0.69 & 23.00 & 115.92 & 3.15 & 529 & 3.14 & 528 \\
\hline October & 0.48 & 15.48 & 80.62 & 0.47 & 15.16 & 78.96 & 2.27 & 381 & 2.27 & 381 \\
\hline November & 0.25 & 8.33 & 42.00 & 0.25 & 8.33 & 42.00 & - & - & - & - \\
\hline December & 0.16 & 5.16 & 26.90 & 0.15 & 4.84 & 25.20 & - & - & - & - \\
\hline Total & 15.52 & & 2607.40 & 15.20 & & 2553.6 & 30.83 & 5180 & 30.50 & 5124 \\
\hline
\end{tabular}


Thirty trees were devoted for this study whereas the experimental treatments were arranged in a complete randomized block design with five replicates and each replicate was represented by a single tree. Four limbs well distributed were selected on each tree and labeled to determined the following parameters:

1- Vegetative growth: shoot length $(\mathrm{cm})$, leaf area $\left(\mathrm{cm}^{2}\right)$ by Li-core 3100 Area meter, leaf dry weight (\%), number of leaves/shoot and foliation (\%).

Leaf dry weight $(\%)=$ Leaf fresh weight - leaf dry weight / leaf fresh weight $\times 100$.

Foliation $(\%)=$ Number of vegetative buds / total number of buds $\times 100$.

\section{2- Fruiting attributes:}

Flowering $\%$, fruit set $\%$ and fruit drop $\%$ on the tagged limbs were calculated as the following:

Flowering $(\%)=$ number of flower buds / total number of buds $\times 100$.

Fruit set $(\%)=$ number of set fruitlets / total number of flowers $\times 100$

Regarding fruit drop \%: the number of fruits retained till harvest time were counted. The fruit drop \% was estimated as the following equation:

Fruit drop $(\%)=$ number of dropped fruitlets / Initial number of set fruitlets $\times 100$ Fruit yield/tree $(\mathrm{kg})$ at pick up date as well as number of fruits/tree.

3- Fruit quality: fruit weight (g.), fruit size $\left(\mathrm{cm}^{3}\right)$, firmness (lb/inch $\left.{ }^{2}\right)$ by using pressure tester, fruit juice T.S.S. by hand refractometer and juice titratable acidity (\%) as A.O.A.C., (1985).

4- Root distribution: soil samples were taken on November 2011 at 0-30, 30-60 and $60-90 \mathrm{~cm}$ depth at $1.50 \mathrm{~m}$ from the tree trunk (at 1/2 canopy distance) in the four directions. Root length ( $<2,2-6$ and $>6 \mathrm{~mm}$ root thick) was assessed $(\mathrm{cm})$ and root dry weight (g.) as g./hole $\left(1750.8 \mathrm{~cm}^{3}\right.$ or $1.628 \mathrm{~kg}$ soil) according to Cahoon et al., (1959) and Ford (1962).

- Water use efficiency (WUE) is used to describe the relationship between production and the amount of water used. It was determined according to the following equation:

WUE $=$ fruit yield $(\mathrm{kg}$.$) / feddan \div$ irrigation rate $\left(\mathrm{m}^{3} /\right.$ feddan/year) $($ Vites, 1965$)$

\section{- Weeds survey (fresh weight (g.) of broad, narrow weeds and percentage of dry weight of broad and narrow leaf weeds):}

Weeds were taken from one square meter of each plot. Weeds were classified into two groups i.e., narrow and broad leaf weeds, the fresh weight of each class were determined in grams $/ \mathrm{m}^{2}$ and the $\%$ dry weight each class.

The obtained data were subjected to analysis of variance according to Snedecor and Cochran (1990). Means were compared using the LSD test at $5 \%$ level of probability. 


\section{RESULTS}

\section{- Growth parameters:-}

Growth parameters included shoot length, leaf area, leaf dry weight (\%), number of leaves/shoot and percentage of foliation as affected by cvs. and irrigation methods is presented in (Table 4). The herein data showed a non-significant effect of irrigation system on shoot length and percentage of foliation in both seasons while the increments of number of leaves/shoot was only in 2010 season and leaf area only in second season under drip irrigation system. However, the studied plum cvs. produced higher significant leaf dry weight percentage under flood irrigation system (44.11 and $42.33 \%$ ) in the two seasons, respectively.

Meanwhile, Dorado plum cv. produced largest leaves $\left(25.27\right.$ and $\left.25.39 \mathrm{~cm}^{2}\right)$ and much more leaf dry weight percentage (44.02 and $42.00 \%$ ) as well as tallest shoots (in 2011 season) and the differences mostly were significant. Santa Rosa plum cv. supported much more significant foliation (29.83 and $30.30 \%$ ) and more nonsignificant leaves/shoot (31.51). Also, Japanese cv. produced tallest shoots (61.82 $\mathrm{cm}$ ) with more leaves (30.77) in the $1^{\text {st }}$ season but the differences were not confirmed statistically.

Concerning the interaction effect, Dorado cv. Produced the tallest shoots and largest leaves under the two studied irrigation systems and gained much significant dry weight percentage under flood system (46.93 and $43.0 \%$ ). Meanwhile, much more foliation ( 31.45 and $32.13 \%$ ) and more leaves were under drip irrigation system with Santa Rosa plum cv. of these difference was significantly.

\section{- Fruiting attributes:-}

Table (5) present the studied fruiting parameters (flowering, fruit set, fruit drop, fruit yield and number of fruits/tree). However, drip irrigation system supported higher flowering percentage, fruit yield and number of fruits/tree (in 2011 season only) as well as fruit set (in both seasons). Otherwise, flood irrigation system encouraged higher percentage of flowering, fruit yield and number of fruits/tree (only in the $1^{\text {st }}$ season) and less fruit drop in 2010 (2.59\%) and 2011 (2.35\%) than drip system (5.11 and $3.32 \%)$, respectively. However, most of these differences were non-significant.

Japanese plum cultivar scored highest fruit set (13.86 and $14.07 \%)$, fruit yield ( 37.13 and $41.10 \mathrm{~kg}$ ) as well as number of fruits/tree (632.5 and 650) in both studied seasons, respectively and mostly with significant differences. Dorado plum cv. recorded the highest flowering $\%$ in the $1^{\text {st }}$ season while Santa Rosa was the highest in the $2^{\text {nd }}$ season. Moreover, Dorado cv. significantly scored the least fruit drop (1.79 and $1.45 \%$ ) while Santa Rosa provided higher fruit yield in 2011 season (41.29 kg).

Besides, the studied plum cultivars showed increasingly increment in the $2^{\text {nd }}$ season compared to the first one specially with fruit yield and number of fruits/tree, 
but most of these differences were non-significant. The interaction effect cleared that Japanese $\mathrm{cv}$. produced the highest number of fruits under the two studied irrigation systems $(616.7,650,648.3$ and 650$)$ as well as produced the highest fruit set percentage (14.10, 14.50, 13.62 and $13.63 \%)$. Also, Santa Rosa cv. produced the highest fruit yield under drip system in the $2^{\text {nd }}$ season $(42.26 \mathrm{~kg})$. While Dorado cultivar showed the least percentage of fruit drop through 2010 and $2011(2.38,1.98,1.19$ and 0.92 $\%)$, respectively.

\section{- Fruit quality:-}

Fruit weight, size and firmness as well as fruit juice T.S.S. and acidity appeared the fruit quality attributes (Table 6) however, the tested plum trees produced heavier and larger fruits with higher soluble solids and lower acidity (only in 2011 season) juice under drip irrigation system although that results did not confirm statistically. Moreover, plum trees resulted in more suitable firmness fruits (8.45 and 8.88 $\mathrm{lb} /$ inch $^{2}$ ) under drip system in both studied seasons, respectively with confirmed statistics. Santa Rosa cultivar could get plum fruits with higher weight (60.48 and $70.17 \mathrm{~g}$.$) and$ size ( 60.34 and $70.17 \mathrm{~cm}^{3}$ ) with more suitable firmness (9.59 and $\left.9.94 \mathrm{lb} / \mathrm{inch}^{2}\right)$ in 2010 and 2011 seasons, respectively and mostly with significant differences. Santa Rosa and Japanese fruit juice has higher T.S.S than Dorado cv. (11.67 and $10.0 \%$ ) which also has higher acidity (1.07 and $1.22 \%$ ) in the two studied seasons, respectively. Moreover, Japanese cv. was superior with juice T.S.S. in the $2^{\text {nd }}$ season $(12.25 \%)$ with the least acidity (0.89 and $1.11 \%$ ) in 2010 and 2011 seasons, respectively.

The interaction effect showed that Santa Rosa cultivar produced fruits with more weight and size under flood and drip irrigation systems while the fruit juice of Santa Rosa and Japanese cvs. has higher T.S.S. While Dorado cultivar showed the least value of all fruit quality properties through 2010 and 2011 seasons, respectively.

\section{- Root system study:}

\section{A. Root length:-}

The studied plum trees produced much longer fine roots (less than $2 \mathrm{~mm}$ thick), medial (2-6 mm) and thick roots (> 6mm) under drip irrigation system (1579.0, 87.1 and $12.1 \mathrm{~cm})$ than flood system $(293.0,49.4$ and $11.4 \mathrm{~cm})$ and the differences were statistically confirmed with fine and medial roots Table (7). However, fine and medial roots were longer within the soil surface layer $(1557$ and $72 \mathrm{~cm}$ ) then shortened with the soil depth, while skeleton roots ( $>6 \mathrm{~mm}$ thick) were longer within $30-60 \mathrm{~cm}$ in the soil profile $(13.5 \mathrm{~cm})$ than in upper or lower profile. 
EFFECT OF SHIFRING TO DRIP IRRIGATION ON SOME

PLUM CULTIVARS GROWN IN CLAY LOAMY SOIL 
Table 7. Effect of irrigation system (A) and root depth (B) on the root length (cm.)

\begin{tabular}{|c|c|c|c|c|}
\hline $\begin{array}{c}\text { Irrigation } \\
\text { system (A) }\end{array}$ & Depth & $\begin{array}{c}\text { Roots less than } \\
2 \mathrm{~mm} \\
\end{array}$ & Roots 2-6 mm & Roots $>6 \mathrm{~mm}$ \\
\hline \multirow{3}{*}{ Drip } & $0-30$ & 2796 & 93.10 & 10.63 \\
\hline & $30-60$ & 1504 & 86.50 & 13.33 \\
\hline & $60-90$ & 437 & 81.60 & 12.23 \\
\hline \multicolumn{2}{|c|}{ Average $(A)$} & 1579 & 87.07 & 12.06 \\
\hline \multirow{3}{*}{ Flood } & $0-30$ & 319 & 50.83 & 9.03 \\
\hline & $30-60$ & 290 & 48.93 & 13.67 \\
\hline & $60-90$ & 270 & 48.43 & 11.57 \\
\hline \multicolumn{2}{|c|}{ Average $(A)$} & 293 & 49.40 & 11.42 \\
\hline \multirow{3}{*}{ Average (B) } & $0-30$ & 1557 & 71.97 & 9.83 \\
\hline & $30-60$ & 897 & 67.72 & 13.50 \\
\hline & $60-90$ & 353 & 65.02 & 11.90 \\
\hline \multicolumn{5}{|c|}{ L.S.D at $5 \%$ level:- } \\
\hline \multicolumn{2}{|c|}{ Irrigation system $(A)=$} & 28.02 & 1.95 & 0.55 \\
\hline Root depth ( B ) & $=$ & 28.07 & 1.954 & 0.553 \\
\hline Interaction $(A \times$ & $=$ & 39.69 & 2.763 & 0.778 \\
\hline
\end{tabular}

These results apparently showed that, drip irrigation system caused much more longer fine roots within 0-30 cm $(2796 \mathrm{~cm}),. 30-60 \mathrm{~cm}(1504 \mathrm{~cm})$ and 60-90 cm $(437 \mathrm{~cm})$, medium roots within 0-30 cm $(93.1 \mathrm{~cm}), 30-60 \mathrm{~cm}(86.5 \mathrm{~cm}$.$) and 60-90 cm$ $(81.6 \mathrm{~cm})$ and skeleton roots within $0-30 \mathrm{~cm}(10.63 \mathrm{~cm}), 30-60(13.33 \mathrm{~cm}$.) and 60-90 cm $(12.23 \mathrm{~cm})$, respectively with significant differences between fine and medium roots. So drip irrigation system supported longer and deeper root system may be as a result of less water quantity.

\section{B. Root dry weight (g.):-}

Concerning the root dry weight, the present results Table (8) showed that, drip irrigation system supported significant higher dry weight with roots less than 2 $\mathrm{mm}(4.01 \mathrm{~g}$.) and 2-6 mm roots (3.34g.) but less roots $>6 \mathrm{~mm}(2.39 \mathrm{~g}$.) than flood irrigation system (1.34, 2.04 and $4.61 \mathrm{~g}$.), respectively. However, fine roots (4.24 g.) and medium roots $(2.86 \mathrm{~g}$.) concentrated within the soil surface layer $(0-30 \mathrm{~cm})$ particularly under drip irrigation system (7.01 and $3.62 \mathrm{~g}$.). That result clear that, drip system encouraged fine and medium roots. The interaction between the two studied factors showed that, much more dry weight was produced specially with fine roots under drip and flood systems as well as with medium and skeleton roots under drip system while 
much dry weight was with skeleton roots specially with flood irrigation system (3.94, 5.08 and 4.8g.) within 0-30, 30-60 and 60-90 cm soil layers, respectively.

Table 8. Effect of irrigation system (A) and root depth (B) on the root dry weight (g.)

\begin{tabular}{|c|c|c|c|c|}
\hline $\begin{array}{c}\text { Irrigation } \\
\text { system }(A)\end{array}$ & Depth & $\begin{array}{l}\text { Roots less than } \\
2 \mathrm{~mm}\end{array}$ & Roots 2-6 mm & Roots $>6 \mathrm{~mm}$ \\
\hline \multirow{3}{*}{ Drip } & $0-30$ & 7.01 & 3.62 & 2.04 \\
\hline & $30-60$ & 3.92 & 3.33 & 2.72 \\
\hline & $60-90$ & 1.10 & 3.07 & 2.40 \\
\hline \multicolumn{2}{|c|}{ Average $(A)$} & 4.01 & 3.34 & 2.39 \\
\hline \multirow{3}{*}{ Flood } & $0-30$ & 1.47 & 2.09 & 3.94 \\
\hline & $30-60$ & 1.30 & 2.06 & 5.08 \\
\hline & $60-90$ & 1.26 & 1.98 & 4.80 \\
\hline \multicolumn{2}{|c|}{ Average $(A)$} & 1.34 & 2.04 & 4.61 \\
\hline \multirow{3}{*}{ Average (B) } & $0-30$ & 4.24 & 2.86 & 2.99 \\
\hline & $30-60$ & 2.61 & 2.70 & 3.90 \\
\hline & $60-90$ & 1.18 & 2.53 & 3.60 \\
\hline \multicolumn{5}{|c|}{ L.S.D at $5 \%$ level:- } \\
\hline \multicolumn{2}{|c|}{ Irrigation system $(A)=$} & 0.482 & 0.214 & 0.484 \\
\hline Root depth ( B ) & $=$ & 0.490 & 0.215 & 0.487 \\
\hline Interaction $(A x$ & $=$ & 0.693 & 0.304 & 0.688 \\
\hline
\end{tabular}

\section{- Water use efficiency:}

Water use efficiency as fruit yield $(\mathrm{kg}$.$) / feddan/irrigation rate \left(\mathrm{m}^{3} /\right.$ feddan/year) was significant higher under drip irrigation system (1.94 and $2.50 \mathrm{~kg} / \mathrm{m}^{3}$ ) than under flood system ( 0.99 and $\left.1.19 \mathrm{~kg} / \mathrm{m}^{3}\right)$ in 2010 and 2011 seasons, respectively (Table 9). It is also noticed that Japanese (1.79 and 2.04) and Santa Rosa (1.63 and 2.05) plum cultivars produced significantly higher water use efficiency than Dorado cv. $\left(0.98\right.$ and $\left.1.45 \mathrm{~kg} / \mathrm{m}^{3}\right)$ in both studied seasons, respectively. Water use efficiency clearly increased from the $1^{\text {st }}$ studied season to the $2^{\text {nd }}$ one may be as a result of the plum trees adapted with the applied drip irrigation system. 
Table 9. Effect of irrigation system and plum cultivars on water use efficiency.

\begin{tabular}{|c|c|c|c|}
\hline \multirow{2}{*}{$\begin{array}{l}\text { Irrigation system } \\
\text { (A) }\end{array}$} & \multirow{2}{*}{ Plum cultivars (B) } & \multicolumn{2}{|c|}{ Water use efficiency $\left(\mathrm{kg} / \mathrm{m}^{3}\right)$} \\
\hline & & 2010 & 2011 \\
\hline \multirow{3}{*}{ Drip } & Japanese & 2.35 & 2.74 \\
\hline & Dorado & 1.31 & 1.97 \\
\hline & Santa Rosa & 2.16 & 2.78 \\
\hline \multicolumn{2}{|c|}{ Average $(A)$} & 1.94 & 2.50 \\
\hline \multirow{3}{*}{ Flood } & Japanese & 1.23 & 1.33 \\
\hline & Dorado & 0.64 & 0.92 \\
\hline & Santa Rosa & 1.10 & 1.32 \\
\hline \multicolumn{2}{|c|}{ Average $(\mathrm{A})$} & 0.99 & 1.19 \\
\hline \multirow{3}{*}{ Average (B) } & Japanese & 1.79 & 2.04 \\
\hline & Dorado & 0.98 & 1.45 \\
\hline & Santa Rosa & 1.63 & 2.05 \\
\hline \multicolumn{4}{|l|}{ L.S.D at $5 \%$ level:- } \\
\hline \multicolumn{2}{|l|}{ Irrigation system $(A)=$} & 0.215 & 0.214 \\
\hline \multicolumn{2}{|l|}{ Cultivars $(B) \quad=$} & 0.215 & 0.214 \\
\hline Interaction $(A \times B)$ & & 0.304 & 0.305 \\
\hline
\end{tabular}

\section{- Weed spread:}

The results in Table (10) showed that, fresh weight of narrow and broad leaf weeds were significant higher spread under flood irrigation system (385.7 and 36.9 g.) than drip system (86.31 and 15.9 g.), respectively.

The percentage of dry weight of narrow and broad leaf weeds were more under drip system (23.67 and $18.67 \%$ ) than under flood system (21.67 and 17.67 $\%)$, respectively although the differences were not significant with broad-leaf weeds.

Table 10. Effect of irrigation system on fresh weight of weeds and percentage of dry weight of broad and narrow leaf weeds.

\begin{tabular}{|l|c|c|c|c|}
\hline \multirow{2}{*}{$\begin{array}{c}\text { Irrigation } \\
\text { system (A) }\end{array}$} & \multicolumn{2}{|c|}{ Fresh weight of weeds (g.) } & \multicolumn{2}{c|}{$\%$ dry weight of weeds } \\
\cline { 2 - 5 } & Broad & Narrow & Broad & Narrow \\
\hline Drip & 15.90 & 86.31 & 18.67 & 23.67 \\
\hline Flood & 36.90 & 385.67 & 17.67 & 21.67 \\
\hline L.S.D. at 5 \% & 3.120 & 4.030 & 1.440 & 1.480 \\
\hline
\end{tabular}

\section{DISCUSSION AND CONCLUSSION}

The herein results clearly showed an increment in most growth parameters, fruit attributes, fruit quality, root system study (root length and root dry weight) and water use efficiency with significant differences in the most cases under drip irrigation system. 
Japanese plum cultivar produced the longest shoots, more number of leaves, fruit yield, fruit size and water use efficiency (in 2010 season) as well as more fruits and less acidity (in 2010 and 2011 seasons). Also, Santa Rosa cv. succeeded of producing more leaves, flowering percentage, fruit size and water use efficiency (in 2011 season) as well as much foliation percentage, heavier fruits and more suitable fruit firmness in the two studied seasons. Otherwise, Dorado plum cv. produced much expanded leaves with much percentage dry weight with less fruit drop percentage (in 2010 and 2011 seasons), longer shoots and more fruit yield (in 2011 season).

However, the significant increment of water use efficiency (WUE) with drip irrigation system $\left(1.94\right.$ and $\left.2.50 \mathrm{~kg} / \mathrm{m}^{3}\right)$ than in flood system $\left(0.99\right.$ and $\left.1.19 \mathrm{~kg} / \mathrm{m}^{3}\right)$ may be as a result of increase WUE with less water consumption. Levin et al., (1979) pointed out that drip irrigation enables a restricted volume of wetted soil to be maintained with small fluctuations in water tension and with the development of a dense root system with minimum loss of water and fertilizers by leaching. Also, Levin et al., (1980) stated that, root distribution depended upon the volume of wetted soil, which was related to soil hydraulic conductivity, the rate and duration of water application. The present results clearly mean about the same plum fruit yield (30.10 and $37.98 \mathrm{~kg}$ ) under drip irrigation system with $1 / 2$ irrigation water rate (2607.4 and $2553.6 \mathrm{~m}^{3} /$ feddan/year) against (5180 and $5124 \mathrm{~m}^{3} /$ feddan/year) under flood system in the two studied seasons, respectively. This great result save $1 / 2$ of irrigation rate, so means less costs, less leaching of nutrients into ground water and less drainage problems (Hanks, 1983). However, many other investigators found that irrigation rate $80 \%$ of field capacity induced better yield i.e., Kucukyumuk et al., (2012) on apple and Fathi (1999) on pear as well as Eid et al., (2002) on deciduous fruits.

Drip irrigation system also improved fruit quality parameters (Table 6). Generally, this remark may lead to the fact that, suitable irrigation rate means better fruit quality. However, the same finding was also cleared by Fathi (1999 ), on pear, and Kandil and El-Feky (2006) on apricot. Moreover, Kucukyumuk et al., (2012) stated that, transition to drip irrigation method for apple trees indicated positive consequences on vegetative growth and fruit quality as well as represented a more marketable fruit size (extra and class 1 ) than flood irrigation.

The present results also illustrate that, root length and its dry weight were significantly higher under drip irrigation system specially with roots less than $2 \mathrm{~mm}$ and 2-6 mm roots (Tables $7 \& 8$ ).

Besides, Magness (1952) disclosed that extraction of moisture from soil is roughly proportional to density of pear, apple and lemon feeder root population, so long as all soil contains moisture above the wilting percentage. Also, Ruggiero (1986) 
on apricot cleared that, accumulated water uptake over a whole year was found to be positively correlated with root density. Meanwhile, Fathi (1999) on pears showed that, drip irrigation system with intermediate rate supports roots to penetrate with higher percentages to longer distances and deeper depths.

So we can recommend plum growers on clay loamy soil to converse flood irrigation system (5180 $\mathrm{m}^{3} / \mathrm{fed} /$ year) to drip system $\left(2607.40 \mathrm{~m}^{3} / \mathrm{fed} /\right.$ year) to save about $1 / 2$ of irrigation water, maximize irrigation water benefit with minimum loss of water and fertilizers by leaching. The drip irrigation schedule (Table 3) may be suitable for clay loamy soil.

\section{REFFERENCES}

1. Association of Official Agricultural Chemists (A.O.A.C) 1985. "Official Methods of Analysis" Benjamin Franklin Station, Washington, D.C., U.S.A., 495-510.

2. Brown, L. R. 1999. Feeding nine billions. In L. Storke (Ed. State of the world (1999). Norton and New York p.230.

3. Cahoon, G. A., E. S. Morton, W. W. Jane and M. J. Garber. 1959. Effect of various types of nitrogen fertilization on root density and distribution as related to water infiltration and fruit yield of "Washington navel" orange in a long term fertilizer experiment. Proc. Amer. Soc. Hort. Sci., 74: 289-299.

4. Eid, H. M., Samia, M. El-Marsafawy, M. M. Ibrahim and M. M. Eissa. 2002. Estimation of water needs for orchard trees in the old land. Egyptian Meteorological Authority Meteorological Research Bulletin - ISSN 1687-1014 vol. 17.

5. Fathi, M. A. 1999. Drip irrigation efficiency for pear trees. B- Root system growth and distribution. J. Agric. Sci., Mansoura Univ., 24 (6): 3035-3049.

6. Fatma, I. Abou Grah, S.M Hussein. and T.A. Eid. 2009. Response of persimmon trees on clay loamy soils to different irrigation levels. Annals of Agric. Sc., Moshtohor, vol. 47 (1): 89-108.

7. Ford, H. W. 1962. Thickness of sub soil organic layer in relation to tree size and root distribution of citrus. J. Amer. Soc. Hort. Sci., 82: 177-179.

8. Hanks, R. D. 1983. Yield and Water used relationships. Amer. Soc. Agron., 393411.

9. Hillel, D. 1987. The efficient use of water in irrigation. Principles and Practices for improving irrigation in Arid and Semiarid regions. The world Bank, Washington, Technical paper No. 64. 
10. Jackson, M. L. 1958. Soil Chemical Analysis. Prentice-Hall. Inc. Englewood Clif., N, I. Library Congress, U.S.A.

11. Kandil, E.A. and S. El-Feky. 2006. Effect of soil matric potential on "Canino" apricot trees in sandy soil under drip irrigation. J. Agric. Sci. Mansoura Univ., 31 (9): 5867-5880.

12. Kucukyumuk, C., E. Kacal, A. Ertek, G. Ozturk and Yasemin S. K. Kurttas. 2012. Pomological and vegetative change during transition from flood irrigation to drip irrigation: Starkrimson apple cv. Scientia Hort., 136: 17-23.

13. Layne-Rec, C. S. Tan and R. I. Perry. 1986. Characterization of peach roots in fox sand as influenced by sprinkler irrigation and trees density. J. Amer. Soc. Hort. Sci. 111: 670-677.

14. Levin, I., R. Assaf and B. A. Bravdo. 1979. Soil moisture and root distribution in apple orchard irrigation by trickles. Plant and Soil, 53: 31-140.

15. Levin, I., R. Assaf and B. A. Bravdo. 1980. Irrigation water status and nutrient uptake in an apple orchard. Butterworths, Borough Green UK p.230.

16. Magness, I. R. 1952. Soil moisture in relation to fruit tree functioning. Hort. Congr., London. (C.F. Hort. Abst., 23: 225).

17. Magriso, Y. U. 1981. Studies on some physiological determining the drought resistance of grape. Grand Loznauka 16: 79-86 (C.F. Hort., Abst., 51: 6885).

18. Marler, T. E. and F. S. Davies. 1990. Micro-sprinkler irrigation and growth of young (Hamlin) orange trees. Amer. Soc. Hort. Sci., 115: 45-51.

19. Ruggiero, C. 1986. Water consumption of drip irrigated apricot trees. Rivista-della ort, 70: 35-47. (C. F. Hort. Abst., 58: 3156).

20. Snedecor, G. W. and Cochran, W. G. 1990. Statistical methods. Oxford and J.B.H. Publishing Com. $7^{\text {th }}$ Edition.

21. Vites, F.G. 1965. Increasing water use efficiency by soil management. Amer. Soc. Agron., Madison. 
تحويل نظام الرى بالغمر إلى رى بالتنقيط فى بعض أصناف البرقوق بالأراضى الطينية

\section{شعبان محمد حسين '، مصطفى أحمد فتحى1 ، طارق أحمد عيد²}

$$
\begin{aligned}
& \text { ا . معز بحوث البساتين مركز البحوث الزراعية - الجيزة - دصر }
\end{aligned}
$$

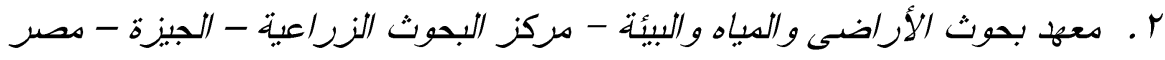

أجريت هذه الدراسة فى المزرعة التجريبية لدحطة بحوث القناطر الخيرية على أثجار برقوق

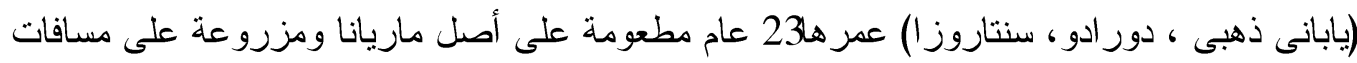
5 × 5 متر فى أرض طينية طييية تحت نظام الرى بالغمر (507.

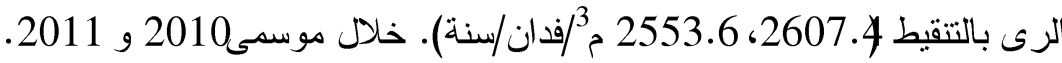

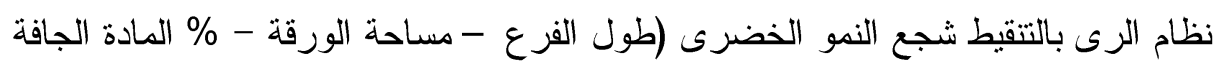

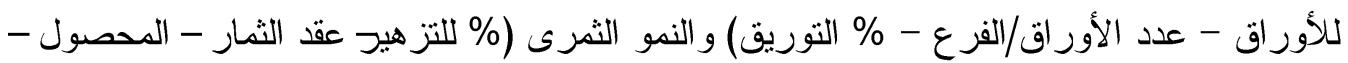

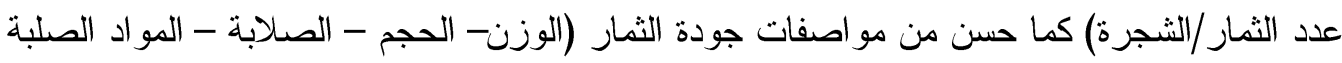

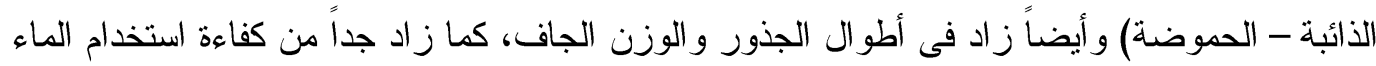

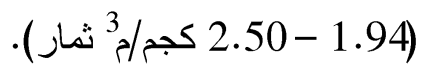

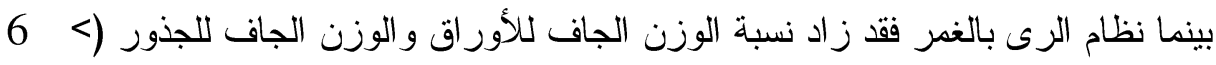

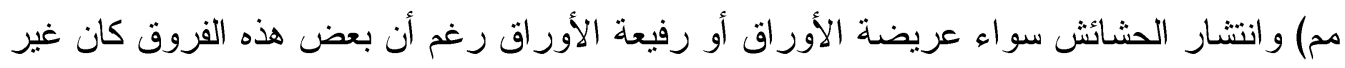
معنوى.

صنف البرقوق يابانى ذهبى أنتج أعلى نسبة عقد و أكبر محصول وعدد الثمار/الثجرة

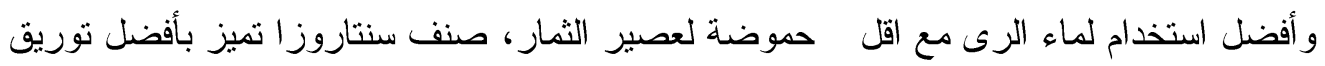
وأفضل وزن وحجم للثمار و أكثر مو اد صلبة كلية فى عصير الثمار مع انسب صلابة للثمار . بينما

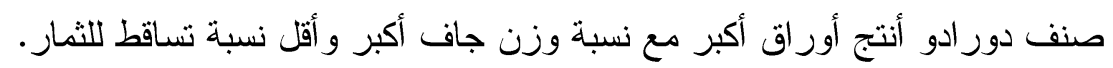

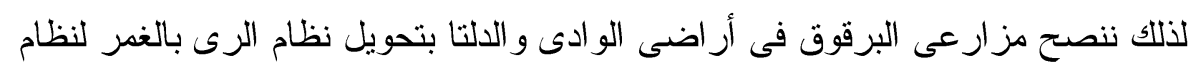

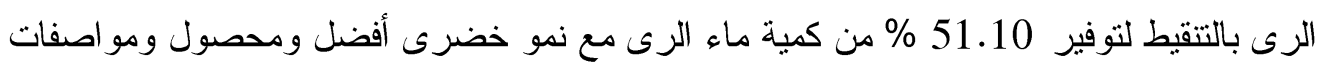

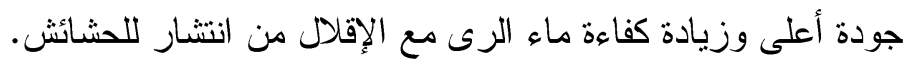

